\title{
Aktivitas Sitotoksik dan Antiproliferasi Fraksi n-Heksan Biji Alpukat (Percea americana Mill.) Terhadap sel T47D
}

\section{Cytotoxic and Antiproliferation Activity of $\mathrm{n}$-Hexane Fraction of Avocado seed (Percea americana Mill) on T47D cell}

\author{
Juwita Rahmawati, *Maryati Maryati \\ Fakultas Farmasi, Universitas Muhammadiyah Surakarta ,Jl. Ahmad Yani, Pabelan, Kartasura, Surakarta 57162 \\ *E-mail: maryati@ums.ac.id
}

Received: 27 Mei 2021; Accepted: 08 Juni 2021; Published: 30 Juni 2021

\begin{abstract}
Abstrak
Tanaman alpukat banyak digunakan dalam pengobatan tradisional di Indonesia. Tujuan penelitian ini untuk mengetahui aktivitas sitotoksik dan antiproliferasi biji buah alpukat terhadap sel T47D. Ekstraksi dilakukan dengan maserasi menggunakan pelarut etanol 96\%. Fraksinasi dilakukan dengan fraksinasi cair-cair dengan pelarut heksan dan etil asetat. Uji sitotoksik dan antiproliferasi dilakukan dengan metode MTT. Pengamatan apoptosis dilakukan dengan double stainning menggunakan campuran acridine orange dan propidium iodide. Hasil uji menunjukkan bahwa fraksi n-heksan memiliki aktivitas sitotoksik dengan nilai IC 50 sebesar 27,9 $\mu \mathrm{g} / \mathrm{mL}$. Fraksi n-heksan mampu menghambat proliferasi sel dan menginduksi apoptosis pada sel T47D.
\end{abstract}

Kata kunci : Percea americana Mill., T47D, MTT, sitotoksik, Apoptosis

\begin{abstract}
Abtract
Avocado plants are widely used as traditional medicine in Indonesia. This research aimed to determine the cytotoxic and antiproliferation activity of avocado seed extract and fractions on the T47D breast cancer cell line. Extraction was done by maceration method using $96 \%$ ethanol, then fractionation was done by liquid-liquid partition using n-hexane, chloroform, and ethyl acetate. Cytotoxic and antiproliferation tests were done by the MTT method. Apoptosis activity was investigated by the double staining method, using acridine orangepropidium iodide as a staining reagent. Results showed that the n-hexane fraction of avocado seed had a cytotoxic activity with $I C_{50} 27.9 \mu \mathrm{g} / \mathrm{mL}$. N-hexane fraction of avocado seed inhibited proliferation and induced apoptosis of T47D cell line.
\end{abstract}

Keywords : Percea americana Mill., breast cancer, MTT, cytotoxic, Apoptosis

\section{PENDAHULUAN}

Kanker payudara memiliki prevalensi yang cukup tinggi. Hingga 2018 tercatat 2,1 juta kasus kanker payudara dengan angka kematian sebesar $627.000(6,6 \%)$ di seluruh dunia (WHO, 2018). Di Indonesia sendiri, angka kejadian kanker payudara hingga tahun 2018 sebanyak 58.256 kasus (WHO, 2019). Kasus kanker payudara diprediksi akan terus meningkat pada tahun-tahun mendatang, terutama pada negara berkembang (Momenimovahed \& Salehiniya, 2019). Terapi kanker payudara yang digunakan saat ini masih memiliki banyak kekurangan, seperti efek samping yang merugikan, efikasi yang kurang, dan mahalnya biaya terapi. Hal tersebut mendorong dilakukannya eksplorasi bahan alam yang berpotensi sebagai agen terapi kanker payudara, salah satunya adalah alpukat. Tanaman alpukat (Percea americana Mill.) diketahui memiliki banyak manfaat bagi kesehatan, diantaranya adalah antihiperglikemi (Ezejiofor et al., 2013), antihipertensi (Désiré et al., 2014), hepatoprotektif (Mahmoed dan Rezq, 2013), antiosteoartritis (Christiansen et al., 2015), dan kemoprotektif (Paul et al., 2011). Selain itu alpukat memiliki aktivitas antioksidan, antibakteri, dan sitotoksik (Melgar et al., 2018). Ekstrak etanol daun alpukat diketahui memiliki aktivitas sitotoksik terhadap sel HeLa, dengan nilai IC $_{50}$ sebesar $360 \mu \mathrm{g} / \mathrm{ml}$ (Mardiyaningsih \& Ismiyati, 2014). Biji alpukat merupakan bagian dari tanaman alpukat dengan aktivitas farmakologi yang 
cukup potensial untuk dimanfaatkan. Berdasarkan penelitian Morcuende et al (2011) biji alpukat menunjukkan aktivitas antioksidan yang tinggi.

Tujuan dari penelitian ini adalah untuk mengetahui aktivitas sitotoksik biji alpukat (Percea americana Mill.) dan mekanisme aksinya terhadap sel kanker payudara T47D. Hasil penelitian ini diharapkan dapat menjadi dasar pengembangan biji alpukat sebagai agen terapi kanker payudara dan menjadi kontribusi positif dalam perkembangan pengobatan kanker payudara.

\section{METODE PENELITIAN Alat dan Bahan}

Alat yang digunakan yaitu timbangan analitik (Precisia, XT 120A), rotary evaporator (IKA RV8), waterbath (Heidolph), inkubator $\mathrm{CO}_{2}$ (Binder), cytotoxic safety cabinet (ESCO), ELISA reader (Elx800 Bio-tech), inverted microscope (Olympus), mikropipet (Socorex), hemositometer (Neubauer) kamera mikroskop (Optilab), confocal laser scanning microscope (Zeis 900).

Bahan yang digunakan: biji alpukat (Persea americana Mill.) yang diperoleh dari Desa Nargoyoso Kemuning Tawangmangu, Kabupaten Kranganyar, sel kanker payudara T47D dan sel normal (Vero), etanol 96\%, nheksan, kloroform, etil asetat, aquadest, RPMI 1640 (Rosewell Park Memorial Institue) (Gibco), $\mathrm{NaHCO}_{3}$ (Merck), DMSO $10 \%$ (Merck), $\mathrm{HCl} 1 \mathrm{M}$ (Merck), $\mathrm{NaOH} 1 \mathrm{M}$ (Merck), FBS 10\% (Fetal Bovine Serum) (Gibco), antibiotik penisilin-streptomisin 3\% (Gibco), tripsin $0,025 \%$ (Sigma), PBS (Phosphat Buffered Saline) (Invitrogen), reagen MTT (3-(4,5-dimetiltiazol-2-il) difenil tetrazolium bromida) (Invitrogen), larutan SDS (Sodium Dodesil Sulfate) (Merck), acridine orange (Merck), propidium iodide (Merck),doxorubicin (Kalbe), well plate 96 (Iwaki), well plate 24 (Iwaki), plastic round cover slips (Thermanox, Fisher Scientific).

\section{Ekstraksi dan Fraksinasi}

Biji alpukat dipotong kecil-kecil, kemudian dikeringkan. Simplisia kering dimaserasi menggunakan etanol 96\%, remaserasi dilakukan 2x. Pengentalan ekstrak dilakukan menggunakan rotary evaporator dilanjutkan dengan waterbath. Ekstrak kental yang diperoleh, selanjutnya difraksinasi caircair dengan pelarut $\mathrm{n}$-heksan, kloroform, dan etil asetat, sehingga diperoleh 3 fraksi cair. Fraksi cair diuapkan menggunakan rotary evaporator dan waterbath hingga diperoleh fraksi kental. Ekstrak dan fraksi selanjutnya diuji aktivitas sitotoksiknya.

\section{Uji Sitotoksik}

Suspensi sel T47D dalam medium RPMI 1640 sebanyak $100 \mu$ l (kepadatan $10^{4}$ sel/sumuran) dimasukkan ke dalam wellplate 96 dan diinkubasi selama 24 jam dalam inkubator $\mathrm{CO}_{2} 5 \%$. Kemudian ditambahkan $100 \mu \mathrm{l}$ seri konsentrasi sampel dalam medium pada tiap sumuran. Plate diinkubasi dalam inkubator $\mathrm{CO}_{2} 5 \%$ selama 24 jam pada suhu $37^{\circ} \mathrm{C}$. Setelah itu ditambahkan $100 \mu \mathrm{l}$ MTT $0,01 \%$ dalam PBS, diinkubasi selama 2 jam pada suhu $37^{\circ} \mathrm{C}$. Sel hidup akan bereaksi dengan MTT membentuk formazan tidak larut yang berwarna ungu. Selanjutnya ditambahkan larutan stopper SDS dalam $\mathrm{HCl}$ $10 \%$ dan ditutup rapat dengan alumunium foil. Plate diinkubasi selama semalam pada suhu ruang. Serapan dari formazan dibaca dengan elisa reader pada panjang gelombang $550 \mathrm{~nm}$. Persentase sel hidup dihitung dari data absorbansi. Selanjutnya dibuat kurva hubungan log konsentrasi versus viabilitas sel untuk menghitung nilai $\mathrm{IC}_{50}$ nya (CCRC, 2012)

\section{Uji Selektivitas}

Sel Vero dengan kepadatan $10^{4}$ ditanam dalam plate 96 dan diinkubasi semalam. Sel diberi perlakuan dengan fraksi n-heksan dengan konsentrasi 25; 50; 75; 100; 125 $\mu \mathrm{g} / \mathrm{ml}$ dan diinkubasi selama 24 jam. Larutan MTT 0,01\% ditambahkan ke dalam sumuran dan diinkubasi selama 2 jam, selanjutnya ditambah larutan stoper SDS dalam $\mathrm{HCl} 10 \%$, plate dibungkus dengan alumunium foil dan 
diinkubasi dalam suhu ruang selama semalam. Serapan dari formazan dibaca dengan elisa reader pada panjang gelombang $550 \mathrm{~nm}$. Selanjutnya ditentukan nilai $\mathrm{IC}_{50}$ pada sel Vero. Nilai selektivitas dihitung menggunakan rumus berikut :

$$
S I=\frac{I C 50 \text { pada sel normal }}{\text { IC50 pada sel kanker }}
$$

Ekstrak dikatakan kurang selektif bila $\mathrm{SI}<3$ dan selektif jika SI>3 (Sutejo et al., 2016).

\section{Uji Antiproliferasi}

Pengamatan penghambatan proliferasi fraksi n-heksan terhadap sel T47D dilakukan dengan metode MTT. Konsentrasi sampel yang digunakan adalah konsentrasi di bawah nilai IC $_{50} \quad(15 \mu \mathrm{g} / \mathrm{ml}$ dan $10 \mu \mathrm{g} / \mathrm{ml})$. Pengamatan viabilitas sel dilakukan pada jam ke 0, 24, 48 dan 72 (CCRC, 2009). Hasil absorbansi digunakan untuk menghitung viabilitas sel. Nilai doubling time, dihitung dengan membuat grafik hubungan lama inkubasi versus log jumlah sel hidup, sehingga didapatkan persamaan regresi liniear $\mathrm{Y}=\mathrm{Bx}+\mathrm{A}$. Selanjutnya $\mathrm{Y}$ adalah nilai $\log 2$ kali jumlah sel hidup di awal, dan $X$ adalah nilai doubling time (Wati et al., 2016).

Pengamatan apoptosis dengan double stainning menggunakan acridine orange dan propidium iodide.

Sel T47D dengan kepadatan $5 \times 10^{4}$ ditanam pada 24-well plate yang telah diberi cover slips pada dasar sumuran sebagai tempat menempelnya sel. Setelah inkubasi selama semalam, sel diberi perlakuan dengan fraksi n-heksan biji alpukat konsentrasi 15 $\mu \mathrm{g} / \mathrm{ml}$ dan $25 \mu \mathrm{g} / \mathrm{ml}$ dan diinkubasi selama 24 jam (CCRC, 2009a). Campuran acridine orange $0,1 \%$ dan propidium iodide $0,1 \%$ (dicampur dan diencerkan hingga konsentrasi 0,05\%), digunakan untuk pewarna sel. Cover slips diambil dari sumuran dan ditetesi $10 \mu \mathrm{L}$ campuran pewarna, kemudian diamati di bawah confocal laser scanning microscope.

\section{Analisis Statistik}

Analisis statistik dilakukan menggunakan aplikasi SPSS versi 20. Uji paired $T$ Test dilakukan untuk menilai signifikansi perbedaan nilai doubling time antara kelompok perlakuan dan kelompok kontrol.

\section{HASIL DAN PEMBAHASAN}

Penelitian ini dilakukan uji aktivitas sitotoksik ekstrak etanol, fraksi heksan, fraksi etil asetat biji buah alpukat terhadap sel T47D. Doksorubisin digunakan sebagai kontrol positif. Hasil uji menunjukkan bahwa fraksi heksan memiliki aktivitas paling tinggi dibanding sampel yang lain dengan nilai IC $_{50}$ sebesar 27,9 $\mu \mathrm{g} / \mathrm{mL}$ (Tabel 1), maka penelitian selanjutnya dilakukan terhadap fraksi n-heksan tersebut. Gambar 2 menunjukkan bahwa dengan adanya kenaikan konsentrasi fraksi n-heksan menyebabkan penurunan viabilitas sel (fenomena dose dependent).

Aktivitas sitotoksik fraksi n-heksan biji alpukat menimbulkan perubahan morfologi sel T47D. Sel T47D yang tidak diberi perlakuan fraksi $n$ heksan terlihat berbentuk bulat pejal dan berwarna terang transparan dengan nukleus yang utuh. Perlakuan fraksi n-heksan biji alpukat menyebabkan perubahan morfologi sel T47D menjadi bentuk saling beragregasi, dan terlihat gelap. Terlihat juga tidak ada perbedaan morfologi yang nyata antara sel kontrol dan sel T47D dengan perlakuan DMSO konsentrasi 0,125\% v/v (Gambar 2).

Tabel 1. Aktivitas sitotoksik ekstrak etanol, fraksi n-heksan, fraksi kloroform, fraksi etil asetat biji alpukat dan doksorubisin

\begin{tabular}{cc}
\hline Sampel & IC50 $(\boldsymbol{\mu g} / \mathbf{m L})$ \\
\hline Ekstrak & $203,1 \pm 29$ \\
Fraksi n-heksan & $27,9 \pm 4,3$ \\
Fraksi kloroform & $214 \pm 148$ \\
Fraksi etil asetat & Tidak dapat dihitung \\
Doksorubisin & $8,47 \pm 4,2$ \\
\hline
\end{tabular}




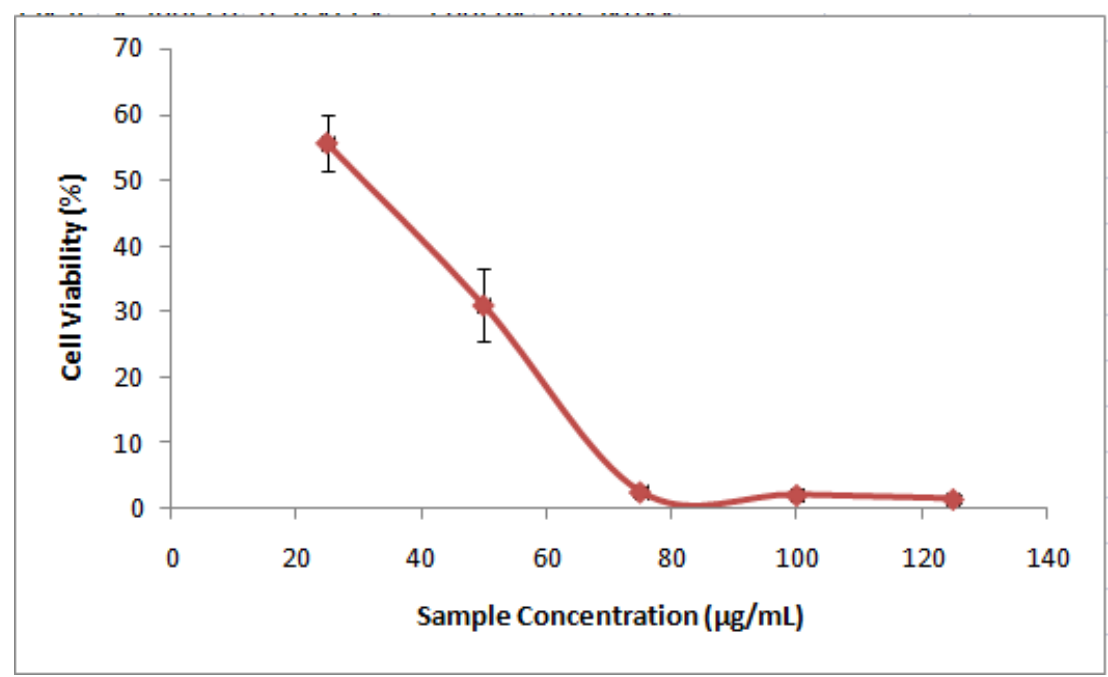

Gambar 1. Kenaikan konsentrasi fraksi n-heksan menyebabkan penurunan viabilitas sel T47D (\%). Sel T47D diinkubasi dengan berbagai konsentrasi fraksi heksan selama 24 jam. Penentuan jumlah sel hidup dilakukan dengan metode MTT.

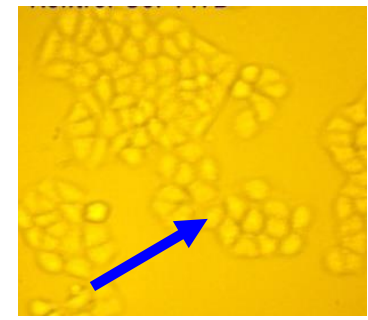

A

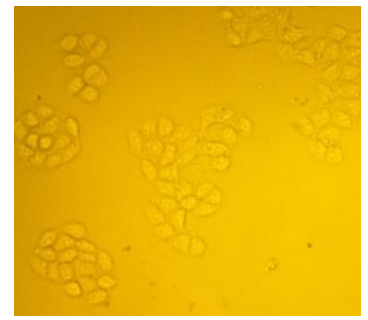

B

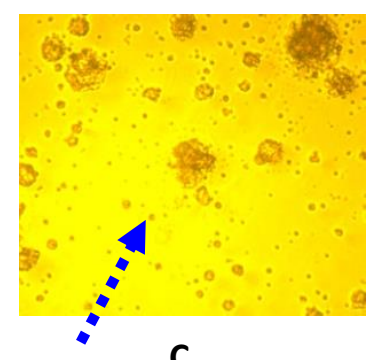

C

Gambar 2. Morfologi kontrol sel T47D (A), sel T47D dalam DMSO konsentrasi 0,125\% (B), sel T47D yang mendapat perlakuan fraksi n-heksan $125 \mu \mathrm{g} / \mathrm{mL}$ (C). Sel kontrol dan sel dalam DMSO 0,125\% tidak berbeda nyata, tetapi ada perbedaaan nyata antara sel kontrol dan sel akibat perlakuan dengan fraksi heksan $125 \mu \mathrm{g} / \mathrm{ml}$. ( $\longrightarrow$ ) adalah sel hidup, dan ( - - ) adalah sel mati.

Hasil penelitian ini sejalan dengan penelitian sebelumnya, yang menyebutkan bahwa asam lemak yang terkandung dalam fraksi n-heksan biji alpukat dapat menghambat pertumbuhan sel kanker kolon (Caco-2) dengan nilai $\mathrm{IC}_{50} 28 \mu \mathrm{g} / \mathrm{mL}$ (LaraMárquez et al., 2020). Selain asam lemak, isolat triterpenoid yang terkandung dalam biji alpukat juga dapat menghambat sel kanker payudara (MCF7) dan kanker hepar (Hep-G2) dengan nilai $\mathrm{IC}_{50}$ berturut-turut $62 \mu \mathrm{g} / \mathrm{mL}$ dan $12 \mu \mathrm{g} / \mathrm{mL}$ (Nur et al., 2017). Penelitian lain juga menunjukkan aktivitas sitotoksik biji alpukat pada berbagai sel kanker. Ekstrak kloroform biji alpukat mampu menghambat pertumbuhan sel MCF7 dengan nilai IC $_{50}$ 94,87 $\mu \mathrm{g} / \mathrm{mL}$ (Widiastuti et al., 2018). Fraksi n-heksan biji alpukat $(200 \mu \mathrm{g} / \mathrm{mL})$ dapat memberikan penghambatan sebesar $81 \pm 3 \%$ pada pertumbuhan sel kanker paru-paru (A549) (Vo et al., 2019). Ekstrak biji alpukat terbukti memiliki aktivitas sitotoksik pada sel kanker prostat (LNCaP), sel kanker payudara (MCF7), sel kanker kolon (HT29), dan sel kanker paru-paru (H1299) (Dabas et al., 2019). Penelitian sebelumnya pada sel MCF7 juga menunjukkan bahwa ekstrak etanol, fraksi heksan, dan isolat triterpenoid dari biji buah alpukat memiliki aktivitas sitotoksik (Nur et al., 2017).

\section{Uji Selektivitas}

Efek samping merugikan yang terjadi selama kemoterapi kanker payudara seperti kebotakan, gangguan pencernaan, anemia, hingga gangguan seksualitas, muncul karena agen kemoterapi juga merusak sel-sel normal tubuh (Dipiro et al., 2012). Oleh karena itu 
penting untuk menemukan dan mengembangkan agen anti kanker yang selektif hanya bekerja pada sel kanker dan tidak merusak sel-sel normal lainnya. Pada penelitian ini dilakukan uji selektivitas menggunakan sel normal Vero. Sel vero adalah sel normal yang dikultur dari sel ginjal African Green Monkey (Ammerman et al., 2009). Uji ini bertujuan untuk mendapatkan gambaran awal toksisitas fraksi heksan biji buah alpukat terhadap sel normal.

Penilaian selektivitas dilakukan dengan membandingkan nilai $\mathrm{IC}_{50}$ sampel pada sel normal terhadap nilai $\mathrm{IC}_{50}$ sampel pada sel kanker. Sampel dikatakan selektif apabila memiliki nilai SI (Selectivitas Index) $\geq 3$, dan tidak selektif apabila nilai SI < 3 (Sutejo et al., 2016). Hasil uji menunjukkan bahwa fraksi nheksan biji alpukat memiliki nilai IC $_{50}$ sebesar $226,5 \pm 21 \mu \mathrm{g} / \mathrm{mL}$ pada sel vero, sedangkan $\mathrm{IC}_{50}$ fraksi n-heksan biji alpukat terhadap sel T47D adalah 27,9 $\mu \mathrm{g} / \mathrm{mL}$. Nilai SI fraksi nheksan terhadap sel vero adalah 8,12 . Hasil tersebut menunjukkan bahwa fraksi n-heksan biji alpukat selektif terhadap sel normal.

Aktivitas sitotoksik fraksi heksan biji buah alpukat terhadap sel T47D secara umum bergantung pada kemampuan untuk menghambat signal proliferasi dan kemampuan untuk memacu apoptosis dengan berbagai kemungkinan mekanismenya. Untuk mengetahui kemungkinan mekanisme penghambatan proliferasi tersebut, selanjutnya dilakukan uji pengamatan penghambatan proliferasi sel dan pengamatan apoptosis dengan double staining menggunakan propidium iodine-akridin oranye.

\section{Uji Penghambatan Proliferasi sel}

Uji penghambatan proliferasi sel dilakukan dengan metode MTT. Uji ini untuk mengamati efek fraksi n-heksan terhadap waktu penggandaan sel T47D (doubling time). Doubling time adalah waktu yang dibutuhkan sel untuk berkembang menjadi dua kali jumlahnya (Mehrara et al., 2014). Senyawa yang dapat menunda waktu penggandaan sel, diduga dapat menghambat gengen atau protein yang meregulasi cell cycle. Konsentrasi senyawa uji yang digunakan adalah 2 konsentrasi di bawah nilai $\mathrm{IC}_{50}$, agar sel tidak terlalu banyak yang mati pada pengamatan selama 72 jam akibat efek sitotoksik senyawa uji (Maryati et al., 2019). Pada uji pengamatan penghambatan proliferasi sel ini digunakan konsentrasi di bawah nilai $\mathrm{IC}_{50}$ yaitu 10 dan $15 \mu \mathrm{g} / \mathrm{ml}$, dan konsentrasi DMSO $0,02 \%$.

Hasil uji menunjukkan bahwa fraksi nheksan biji alpukat pada konsentrasi di bawah $\mathrm{IC}_{50}$ tidak menghentikan cell cycle tetapi menyebabkan cell cycle arrest yaitu dapat menghambat proliferasi sel T47D (Tabel 2). Hasil penelitian ini sejalan dengan beberapa penelitian sebelumnya. Penelitian Dabas et al., 2019 menyebutkan bahwa pemberian ekstrak biji alpukat dengan konsentrasi 42,5 $\mu \mathrm{g} / \mathrm{mL}$ selama 12 jam dapat menginduksi cell cycle arrest pada fase sub G0/G1 sel kanker prostat (LNCaP). Pemberian ekstrak biji alpukat juga menyebabkan penurunan eksperesi Cyclin D1 dan Cylin E2 tanpa adanya perubahan pada Cyclin A (Dabas et al., 2019). Diketahui bahwa Cyclin D1 dan Cylin E2 adalah protein kinase yang mengatur proses proliferasi sel, dengan cara mengirimkan transduksi sinyal internal pada setiap fase dalam siklus sel (Malumbres \& Barbacid, 2007). Senyawa acetogenin alifatik yang diisolasi dari buah alpukat diketahui dapat menghambat proliferasi sel kanker mulut melalui mekanisme penghambatan fosforilasi EGFR (Epidermal Growth Factor Receptors), ERK 1/2 (Extracelullar-Signal-Regulated-Kinase 1/2), dan c-Raf (Ser 338) dalam proses pertumbuhan sel kanker (D'Ambrosio et al., 2011).

Hasil perhitungan diperoleh bahwa fraksi n-heksan biji alpukat dengan konsentrasi $15 \mu \mathrm{g} / \mathrm{mL}$ mempunyai doubling time sebesar 162,94 jam, sedangkan konsentrasi $10 \mu \mathrm{g} / \mathrm{mL}$ memberikan nilai doubling time sebesar 111,77 jam. Kedua nilai doubling time tersebut berbeda signifikan $(\mathrm{p}<0.05)$ jika dibandingkan dengan nilai doubling time kontrol sel, yaitu 66,01 jam. Nilai doubling time dapat menggambarkan volume pertumbuhan sel kanker, sehingga sering digunakan untuk mengevaluasi efikasi berbagai model terapi anti kanker (Mehrara et al., 2007). 
Tabel 2. Efek Penghambatan Fraksi n-Heksan Biji Buah Alpukat terhadap Sel T47D

\begin{tabular}{cccc}
\hline \multirow{2}{*}{ Waktu (Jam) } & \multicolumn{3}{c}{ \% Penghambatan } \\
\cline { 2 - 4 } & DMSO & $\begin{array}{c}\text { Fraksi } \mathbf{n - H e k s a n} \\
\mathbf{( 1 0} \boldsymbol{\mu g} / \mathbf{m L})\end{array}$ & $\begin{array}{c}\text { Fraksi n-Heksan } \\
\mathbf{( 1 5} \boldsymbol{\mu g} / \mathbf{m L})\end{array}$ \\
\hline 24 & 3,27 & 27,42 & 35,01 \\
48 & 4,22 & 30,23 & 39,19 \\
72 & 223 & 31,73 & 39.33 \\
\hline
\end{tabular}

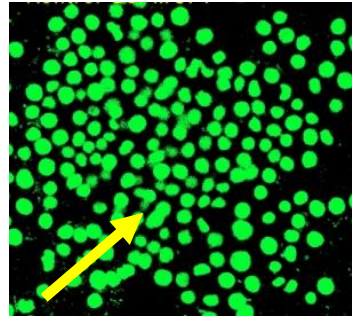

A

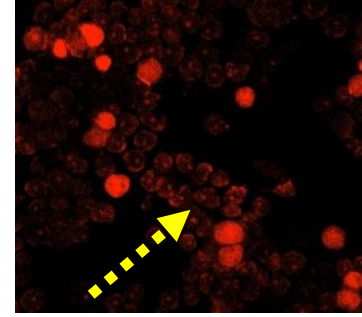

B

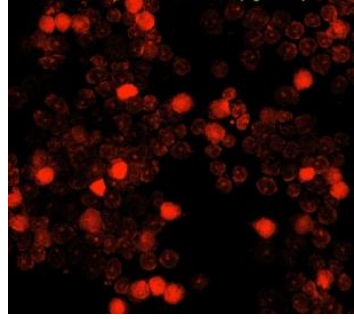

C

Gambar 3. Morfologi sel T47D setelah pengecatan double stainning menggunakan propidium iodineakridin oranye pada sel kontrol (A), perlakuan dengan fraksi heksan $15 \mu \mathrm{g} / \mathrm{ml}$ (B) dan fraksi heksan 25 $\mu \mathrm{g} / \mathrm{ml}(\mathrm{C})$. Pada sel kontrol terlihat sel yang hidup berwarna hijau. Pada perlakuan dengan fraksi heksan terlihat sel mengalami apoptosis (fluorosensi merah) dan terlihat adanya fragmentasi DNA. ( $)$ sel normal $(- \pm)$ ) sel yang kemungkinan apoptosis

\section{Pengamatan Apoptosis dengan double stainning}

Apoptosis adalah proses kematian sel yang terprogram yang secara normal terjadi dalam siklus sel. Fungsi dari apoptosis adalah untuk menghilangkan sel-sel yang berbahaya, sel-sel yang rusak, dan sel-sel yang tidak diinginkan (Alenzi, 2014). Induksi apoptosis memiliki peran penting dalam perkembangan terapi kanker, sebab sel kanker akan menginisasi kematiannya sendiri tanpa merusak sel normal lainnya (Wong, 2011). Uji apoptosis dalam penelitian ini menggunakan metode double stainning dengan campuran acridine orange dan propidium iodide 0,05\% (Foglieni et al., 2001). Sel T47D yang telah diberi perlakuan fraksi n-heksan biji alpukat $(25 \mu \mathrm{g} / \mathrm{mL}$ dan 15 $\mu \mathrm{g} / \mathrm{mL}$ ) kemudian diwarnai dengan campuran acridine orange dan propidium iodide $0,05 \%$. Acridine orange dapat diabsorbsi oleh sel hidup dan sel mati. Acridine orange akan berikatan dengan DNA untai ganda pada sel hidup, menghasilkan fluorosen hijau, sedangkan pada sel mati acridine orange akan berikatan dengan DNA untai tunggal, menghasilkan fluorosen berwarna merah. Propidium idode berinteraksi dengan asam nukleat sel membentuk fluorosen merah, sehingga hanya dapat diabsorbsi oleh sel yang mengalami membrane blebbing. Pada penggunaan bersamaan, propidium iodide akan mengabsorbsi acridine orange pada sel mati, sehingga tidak menyebabkan hasil yang bias (Mascotti et al., 2000). Karakteristik sel yang mengalami apotosis adalah terbentuknya membrane blebbing, penyusutan ukuran sel, fragmentasi organel, dan nuclear condensation (Bjelaković et al., 2005). Hasil uji menunjukkan bahwa pemberian fraksi n-heksan biji alpukat dengan konsentrasi $15 \mu \mathrm{g} / \mathrm{mL}$ dan $25 \mu \mathrm{g} / \mathrm{mL}$ dapat menginduksi apoptosis pada sel T47D. Hal itu terlihat dari sel yang berfluorosensi merah pada sel T47D yang diberi perlakuan fraksi n-heksan, sedangkan kontrol sel T47D (tanpa perlakuan) terlihat sel berfluorosensi hijau (Gambar 3).

Penelitian sebelumnya melaporkan bahwa tanaman alpukat dapat menginduksi apoptosis berbagai sel kanker. Penelitian Veles-Pardo et al (2014) melaporkan bahwa ekstrak kulit buah alpukat, ekstrak biji alpukat, ekstrak bagian dalam biji alpukat, dan ekstrak daun alpukat dapat menginduksi apoptosis pada sel jurkat leukimia 
limfoblastik. Fraksi metanol ekstrak kloroform biji alpukat terbukti dapat meningkatkan $(21,9 \%)$ populasi sel MCF7 yang berada pada fase sub G1 dibandingkan dengan kontrol sel $(3,7 \%)$, hasil tersebut mengindikasikan terjadinya induksi apoptosis pada sel MCF7 (Widiastuti et al., 2018). Penelitian lain melaporkan bahwa ekstrak lipid buah alpukat dapat meningkatkan ekspresi caspase8 dan caspase 9 pada sel kanker kolon (Caco-2) (Lara-Márquez et al., 2020).

Data-data di atas menunjukkan bahwa fraksi n-heksan biji buah alpukat mempunyai kemampuan menghambat proliferasi sel T47D. Penghambatan ini mungkin terjadi pada signal proliferasi atau melalui penghambatan cell cycle progression dengan menghambat protoonkogen seperti $\mathrm{CycD}$ atau cdk4/6. Mekanisme lain diduga dengan memacu terjadinya apoptosis dengan memodulasi ekspresi protein pengatur apoptosis seperti p53, Bax, Bcl-2, dan NOXA. (Velezpardo, 2014). Potensi fraksi n-heksan biji buah alpukat sebagai senyawa antikanker perlu ditelusuri lebih lanjut untuk memastikan mekanisme molekuler aktivitas antikanker tersebut.

\section{KESIMPULAN}

Fraksi n-heksan biji alpukat memiliki aktivitas sitotoksik pada sel kanker payudara T47D dengan nilai $\mathrm{IC}_{50} 27,9 \mu \mathrm{g} / \mathrm{mL}$ dan selektif terhadap sel normal (Vero). Fraksi nheksan biji alpukat dapat menghambat proliferasi sel dan menginduksi apoptosis sel T47D.

\section{Daftar Pustaka}

Alenzi, F. 2014. Links between apoptosis, proliferation and the cell cycle, British Journal Of Biomedical Science, 61(2). https://doi.org/10.1080/09674845.2004.11732652

Ammerman, N. C., Beier-Sexton, M., Azad, A. F. 2009. Growth and Maintenance of Vero Cell Lines Nicole. NIH, 1-10. https://doi.org/10.1002/9780471729259.mca04es11.Growth

Bjelaković, G., Nagorni, A., Bjelaković, M., Stamenković, I., Arsic, R., Katic, V. 2005. Apoptosis: Programmed Cell Death And Its Clinical Implications, Medicines and Biology, 12(1), 6-11.

CCRC. 2009a. Prosedur Tetap Pengamatan Apoptosis Dengan Metode Double Stainning (CCRC-03-011-01).

CCRC. 2009b. Prosedur Tetap Uji Pengamatan Proliferasi Sel (Dubling Time) (CCRC-03-01501).

CCRC. 2012. Prosedur Tetap Uji Sitotoksik Metode MTT (CCRC-03-010-01).

Christiansen, B. A., Bhatti, S., Goudarzi, R., Emami, S. 2015. Management of Osteoarthritis with Avocado / Soybean Unsaponifiables, Sage, 6(1), 30-44. https://doi.org/10.1177/1947603514554992

D’Ambrosio, S. M., Han, C., Pan, L., Kinghorn, A. D., Ding, H. 2011. Aliphatic acetogenin constituents of avocado fruits inhibit human oral cancer cell proliferation by targeting the EGFR/RAS/ RAF/MEK/ERK1/2 pathway, National Institute Of Health, 10; 409(3), 111. https://doi.org/10.1016/j.bbrc.2011.05.027.Aliphatic

Dabas, D., Elias, R. J., Ziegler, G. R., Lambert, J. D. 2019. In Vitro Antioxidant and Cancer Inhibitory Activity of a Colored Avocado Seed Extract. International Journal of Food Science, 2019(2017). https://doi.org/10.1155/2019/6509421

Désiré, P., Dzeufiet, D., Mogueo, A., Bilanda, D. C., Aboubakar, B. O., Tédong, L., Dimo, T., Kamtchouing, P. 2014. Antihypertensive potential of the aqueous extract which combine leaf of Persea americana Mill . ( Lauraceae ), stems and leaf of Cymbopogon citratus ( D .C) Stapf . ( Poaceae ), fruits of Citrus medical L. ( Rutaceae ) as well as honey in ethanol and s. Complementary and Alternative Medicine, 14:507, 1-12. 
Dipiro, J. T., Wells, B. G., Schwingammer, T. L., \& Dipiro, V. C. 2012. Pharmacotherapy Handbook (9th ed.). Mc Graw Hill Education.

Ezejiofor, A. N., Okorie, A., \& Orisakwe, E. 2013. Hypoglycaemic and Tissue-Protective Effects of the Aqueous Extract of Persea Americana Seeds on Alloxan-Induced Albino Rats. Malays J Med Sci, 20(5), 31-39.

Foglieni, C., Meoni, C., \& Davalli, A. M. 2001. Fluorescent dyes for cell viability: An application on prefixed conditions, Springer, 115(April 2001), 223-229. https://doi.org/10.1007/s004180100249

Lara-Márquez, M., Báez-Magaña, M., Raymundo-Ramos, C., Spagnuolo, P. A., MacíasRodríguez, L., Salgado-Garciglia, R., Ochoa-Zarzosa, A., López-Meza, J. E. (2020). Lipid-rich extract from Mexican avocado (Persea americana var. drymifolia) induces apoptosis and modulates the inflammatory response in Caco-2 human colon cancer cells. Journal of Functional Foods, 64(October 2019), 103658. https://doi.org/10.1016/j.jff.2019.103658

Mahmoed, M. Y., dan Rezq, A. A. 2013. Hepatoprotective Effect of Avocado Fruits Against Carbon Tetrachloride-Induced Liver Damage in Male Rats. World Applied Sciences Journal, 21(10), 1445-1452. https://doi.org/10.5829/idosi.wasj.2013.21.10.72160

Malumbres, M., \& Barbacid, M. 2007. Cell cycle kinases in cancer. Elsevier, 17, 60-65. https://doi.org/10.1016/j.gde.2006.12.008

Mardiyaningsih, A., dan Ismiyati, N. 2014. Cytotoxic Activity Of Ethanolic Extract Of Persea americana Mill. Leaves On HeLa Cervical Cancer Cell. Traditional Medicine Journal,Raditional Medicine Journal, 19, 24-28.

Maryati, M., Sutrisna, E., Saifudin, A., Kusumaningrum, I., Abu bakar, M. . 2019. Extract of ceplukan ( Physalis angulata L .) inhibited proliferation and induced apoptosis in myeloma cell line. Food Research, 3(December), 755-760. https://doi.org/10.26656/fr.2017.3(6).169

Mascotti, K., Mccullough, J., \& Burger, S. 2000. HPC viability measurement: Trypan blue versus acridine orange and propidium iodide. Transfusion, 40, 693-696. https://doi.org/10.1046/j.1537-2995.2000.40060693.x

Mehrara, E., Forssell-aronsson, E., Bernhardt, P. 2007. Specific Growth Rate versus Doubling Time for Quantitative Characterization Specific Growth Rate versus Doubling Time for Quantitative Characterization of Tumor Growth Rate, May 2014. https://doi.org/10.1158/0008-5472.CAN-06-3822

Melgar, B., Inês, M., Ciric, A., Sokovic, M., Garcia-castello, E. M., Rodriguez-lopez, A. D., Barros, L., Ferreira, I. C. R. F. 2018. Bioactive characterization of Persea americana Mill . by-products : A rich source of inherent antioxidants, Industrial Crops \& Products, 111(2017), 212-218. https://doi.org/10.1016/j.indcrop.2017.10.024

Momenimovahed, Z., dan Salehiniya, H. 2019. Epidemiological characteristics of and risk factors for breast cancer in the world. Dovepress, 11, 151-164.

Morcuende, D., Kylli, P., Est, M. 2011. Avocado ( Persea americana Mill .) Phenolics, In Vitro Antioxidant and Antimicrobial Activities, and Inhibition of Lipid and Protein Oxidation in Porcine Patties. Journal of Agricultural and Food Chemistry, 59, 5625-5635.

Nur, A., Abubakar, F., Achmadi, S. S., Suparto, I. H. 2017. Triterpenoid of avocado (Persea americana) seed and its cytotoxic activity toward breast MCF-7 and liver HepG2 cancer cells. Asian Pacific Journal of Tropical Biomedicine, 7(5), 397-400. https://doi.org/10.1016/j.apjtb.2017.01.010

Paul, R., Kulkarni, P., Ganesh, N. 2011. Avocado fruit (Persea americana Mill) exhibits chemoprotective potentiality against cyclophosphamide induced genotoxicity in human lymphocyte culture. Journal of Experimental Therapeutics and Oncology, 9(3), 221-230.

Sutejo, I. R., Putri, H., Meiyanto, E. 2016. Selektivitas Ekstrak Etanolik Buah Makassar 
(Brucea javanica ) pada Kanker Payudara Metastasis secara In Vitro.The Selectivity of Ethanolic Extract of Buah Makassar ( Brucea javanica ) on In Vitro Study of Metastatic Breast Cancer, Journal of Agromedicine and Medical Sciences, 2(1), 1-5.

Velez-pardo, C. 2014. Pro-apoptotic effect of Persea americana var. Hass (avocado) on Jurkat lymphoblastic leukemia cells. Informa Healthcare, 52(4), 458-465. https://doi.org/10.3109/13880209.2013.842599

Vo, T. S., Le, P. U., Ngo, D. H. 2019. Free radical scavenging and anti-proliferative activities of avocado (Persea americana Mill.) seed extract. 9(3), 91-97. https://doi.org/10.4103/2221-1691.254602

Wati, E. M., Puspaningtyas, A. R., Pangaribowo, D. A. 2016. Uji Sitotoksisitas dan Proliferasi Senyawa 1- ( 4-nitrobenzoiloksi- metil ) -5-fluorourasil terhadap Sel Kanker Payudara MCF-7 methyl ) -5-fluorouracil ) on Breast Cancer Cells MCF-7). Pustaka Kesehatan, 4(3), 484-488.

WHO. 2018. Latest global cancer data : Cancer burden rises to 18.1 million new cases and 9 . 6 million cancer deaths in 2018 Latest global cancer data: Cancer burden rises to 18.1 million new cases and 9.6 million cancer deaths in 2018. International Agency for Research on Cancer, September, 13-15.

WHO. 2019. Global Cancer Statistics: Indonesia Fact Sheets, International Agency for Research on Cancer, 256, 1-2.

Widiastuti, Y., Pratiwi, R., Riyanto, S., Wahyuono, S. 2018. Persea americana Mill . seed extract on MCF-7 cancer cell line. Indonesian Journal of Biotechnology, 23(2), 61-67. https://doi.org/10.22146/ijbiotech.32141

Wong, R. S. 2011. Apoptosis in cancer; from pathogenesis to treatment. Journal of Experimental \& Clinical Cancer Research, 30:87(2), 1-14. 